\title{
Power AND ACCOUNTABILITY IN THE EU FINANCIAL \\ REGULATORY ARCHITECTURE: EXAMINING INTER-AGENCY RELATIONS, AgENCY INDEPENDENCE AND ACCOUNTABILITY
}

\author{
Iris $\mathrm{H}-\mathrm{Y}$ Chiu*
}

Institutional reforms carried out at the EU level in the aftermath of the global financial crisis were purposed towards preserving the stability and well-functioning of financial markets in the EU. The European System of Financial Supervision was first created, followed by the Single Supervisory Mechanism supported by the Single Resolution Mechanism. The proliferation of European level regulatory and supervisory authorities has recalibrated the exercise of public authority over financial markets, and significant power has shifted from national to European level agencies. The creation of EU level agencies is supported by avenues of formal accountability in political, stakebolder and judicial accountability, resulting in some complex designs in power structures. The article argues that such complex designs may affect the autonomy and technocratic efficacy of institutions. However, there is potential in leveraging upon one aspect the complexity offers- inter-agency coordination, in order to promote learning for technocratic effectiveness as well as to cultivate a form of accountability that ameliorates the perception of excessive power. The paper will focus on the inter-relationships between the three European sectoral agencies, especially in the Foint Committee and Board of Appeal to illustrate the achievements of inter-agency coordination and accountability. The paper will go on to explore new challenges that arise with the introduction of the SSM and SRM into the EU financial regulatory architecture. The paper will argue that promoting inter-agency coordination in specific areas may have the potential to address some of these challenges. The broader notion of inter-agency accountability can also spawn future lines of discourse and research into improving the credibility and legitimacy of the exercise of power by EU level agencies.

Keywords: European System for Financial Supervision, Board of Appeal, Single Supervisory Mechanism, Single Resolution Board, Inter-agency accountability

\section{TABLE OF CONTENTS}

I. INTRODUCTION.

II. THE INSTITUTIONAL ARCHITECTURE IN THE EUROPEAN SYSTEM FOR FINANCIAL SUPERVISION (ESFS) - THE First STAGE OF INTITUTIONAL

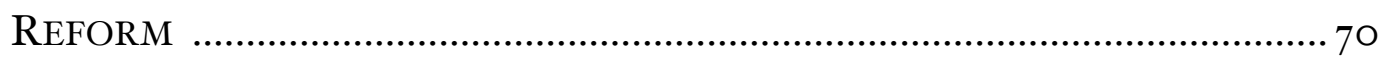

I. An Outline of the ESFS ....................................................................... 73

2. Critically Exploring the Complex Designs in Power and Accountability in the ESFS and Technocratic Effectiveness of the Institutions ......................... 76

III.INTER-AGAENCY LEARNING, COORDINATION, ACCOUNTABILITY 
I. Foint Committee .................................................................................... 85

2. Inter-agency Learning and the Board of Appeal ..................................... 88

3. Inter-agency Coordination and Accountability Generally ...........................9I

IV.THE SSM, SRM AND LESSONS THAT CAN BE LEARNT WITH RESPECT

TO INTER-AGENCY COORDINATION

V. Final OBSERVATIONS AND CONCLUSIONS .IO2

\section{INTRODUCTION}

Institutional reforms carried out at the EU level in the aftermath of the global financial crisis were purposed towards preserving the stability and well-functioning of financial markets in the EU, while not compromising on the integration of the internal market. ${ }^{.}$The European System of Financial Supervision (ESFS) was first created in 2010, followed by the Single Supervisory Mechanism ${ }^{2}$ (SSM) supported by the Single Resolution Mechanism (SRM) in 20I4. The ESFS comprises of three agencies, the European Banking Authority (EBA), the European Securities and Markets Authority (ESMA), the European Insurance and Occupational Pensions Authority (EIOPA), a Joint Committee of the three authorities and the European Systemic Risk Board (ESRB), a dedicated outfit to monitoring systemic risk which is situated under the umbrella of the European Central Bank (ECB). The proliferation of European level regulatory and supervisory authorities has recalibrated the exercise of public authority over financial markets, and significant power has shifted from national to European level agencies. ${ }^{3}$ National legislators and agencies have largely become administrators of EU regulation although the UK has chosen to engage in gold-plating forms of divergence in some aspects. ${ }^{4}$

The shift in financial regulatory power to the EU is not accepted without unease. Hence, the powers vested in the institutions comprising the ESFS and the accountability mechanisms have been subject to rather complex

* PhD, Reader in Laws, Faculty of Laws, University College London. The author thanks Professor Gudula Deipenbrock and Professor Mads Andenas for their invitation to present this paper at the Roundtable on Financial Markets Regulation, HTW Berlin, 5 December 20I4. The author also thanks two anonymous reviewers at the European Journal of Legal Studies. All errors and omissions are mine.

I Jacques de Larosière and others, Report by the High Level Group on Financial Supervision in the $E U$ (Brussels, 25 February 2009) http://ec.europa.eu/internal_market/finances/docs/de_larosiere_report_en.pdf.

${ }^{2}$ See the Council Regulation (EU) No $1024 / 2013$ of 15 October 2013 conferring specific tasks on the European Central Bank concerning policies relating to the prudential supervision of credit institutions [2013] OJ L 287/63 ('SSM Regulation').

${ }^{3}$ Niamh Moloney, 'EU Financial Market Regulation After the Global Financial Crisis: More Europe or More Risks?' (2010) 47 Common Market Law Review I3I7.

${ }^{4}$ See discussion in Mads Andenas and Iris H-Y Chiu, 'Financial Stability and Legal Integration in Financial Regulation' (2013) European Law Review 335. 
designs. ${ }^{5}$ The EU financial regulatory architecture features a complex design of multiple institutions with different responsibilities located in delicately negotiated power and accountability structures that have to be consistent with Treaty foundations and the Meroni doctrine. Complex design continues to be a feature in the institution of the Single Supervisory and Single Resolution Mechanisms.

Complex design reflects the political compromises achieved in sketching the contours of power and accountability relating to the institutions in the ESFS, the SSM and SRM, but the question is whether technocratic effectiveness may be traded off against complex design. This article takes stock of the complexities in the institutional architecture for regulating financial services in the EU and argues there is a need to mediate the needs of technocratic effectiveness and respecting the rationales for the complex designs that have come about. This article argues that exploring the space for inter-agency learning and coordination provides a way for balancing both objectives. This article thus finds the silver lining in the complex designs and makes broad level suggestions to provide perspective. However, it is acknowledged that such a perspective is a starting point and more detailed work can emanate from this research, especially in empirical work, to fully realise the potential of the perspective suggested in this article.

When the ESFS was first institutionalised in 20I0, inter-agency coordination was arguably legislated to be part of the institutional architecture in order to achieve the technocratic effectiveness and efficiency of joined-up thinking without amounting to creating a centralised and monolithic financial regulation agency at the EU level. Such inter-agency coordination between the three European agencies is found in the Joint Committee, the Board of Appeal that reviews any complaint regarding a decision imposed by one of the agencies, and the agencies' coordinated work in assisting the ESRB. The article notes that inter-agency coordination has flourished among the European agencies and critically explores the advantages of such coordination in terms of the development of the agencies' identities, technocratic expertise and interagency accountability.

This article argues that inter-agency coordination and accountability have highlighted perhaps the unintended benefits of the sectoral institutional architecture for regulating financial services in the EU. This albeit complex architecture has provided opportunities for the EU level agencies to boost their effectiveness and technocratic leadership, and offers further research possibilities into inter-agency accountability and improving the legitimacy of EU agencies as part of the 'administrative polity'. Interagency accountability can give rise to the development of novel indicators ${ }^{5}$ Pablo Iglesias-Rodriguez, The Accountability of Financial Regulators (Wolters Kluwer
20I4). 
for accountability, and such accountability could also be made more transparent in order to engage the public in a more informed discourse on the credibility and legitimacy of the exercise of power by EU level agencies. Inter-agency accountability is also an under-explored area that should be studied to see if non-conventional mechanisms of accountability could improve perceptions of legitimacy in EU level institutions, and contribute towards determining the performance of EU level institutions.

The inter-agency model in the ESFS offers useful insights for the subsequent stage of reform in financial regulatory architecture in the EU represented by the advent of the SSM and SRM. There are a number of unresolved issues in the power and accountability structures in the SSM and SRM architecture, and this article will argue that beneficial insights can be gained from the ESFS model to develop solutions for these concerns.

Part II of the article discusses the institutional architecture of the ESFS and how its power structures and accountability mechanisms have successfully constrained power and provided for extensive multiple accountability channels for the new institutions. It however raises the concern that more institutional autonomy may be needed for institutional effectiveness on the part of the EU level agencies. Part III then discusses how inter-agency coordination and accountability provide channels for boosting agency autonomy and technocratic leadership. Part III also engages in a literature review of the concept of inter-agency accountability and its promising aspects. Part IV then turns to the SSM and SRM as the subsequent stage of institutional architectural reform in regulating EU financial services and offers some observations regarding concerns for the coherence and technocratic effectiveness of the new institutions. This Part argues that insights from the three agencies' inter-agency coordination and accountability can contribute towards consolidating the coherence of responsibilities and the achievement of technocratic effectiveness in an appropriate structure of powers in the SSM and SRM designs. Part V concludes.

\section{The Institutional Architecture in THE EURopean System fOr FinANCIAL SUPERVision (ESFS) - The First Stage OF INSTITUTIONAL REFORM}

Since the late I990s legal integration has been identified to be key to market integration in financial services, ${ }^{6}$ and a stealthy form of

\footnotetext{
${ }^{6}$ European Commission, 'Financial Services Action Plan: Implementing the Framework for Financial Markets' (Communication) COM (I999) 232; Alexandre Lamfalussy and others, 'Final Report of the Committee of Wise Men on the Regulation of European Securities Markets' (Brussels, I5 February 200I) http://ec.europa.eu/internal_market/securities/docs/lamfalussy/wisemen/final-reportwise-men_en.pdf; Eilis Ferran, Building an EU Securities Market (CUP 2004).
} 
institutionalisation at the $\mathrm{EU}$ level ${ }^{7}$ for regulating financial services has emerged alongside regulatory convergence. The global financial crisis of $2008^{-} 9$ provided an opportunity for the EU to review the state of financial regulation and reforms that may be needed to address the issues surfaced in the crisis. The European Commission established a high-level group of experts chaired by Jacques de Larosière to recommend a blueprint for financial supervision in the EU. The de Larosière report recommended extensive legal harmonisation and institutionalisation of a European System of Financial Supervision ${ }^{8}$ (ESFS) in order to meet the needs of financial stability and market integration. ${ }^{9}$

The ESFS comprises three pan-European financial regulators (the EBA, ${ }^{10}$ ESMA $^{\text {II }}$ and EIOPA ${ }^{\mathrm{I}}$ ), a Joint Committee of the European Supervisory Authorities and national regulators, and a pan-European macro-prudential supervisor (the $\mathrm{ESRB}^{\mathrm{13}}$ ) formed under the auspices of the European Central Bank.

However, hot on the heels of the creation of the ESFS, the acute problems of weak European banks in the periphery linked to weak sovereigns was threatening to overcome the EU with another series of banking crises, in euro-area countries such as Portugal, Ireland, Greece, Spain, Cyprus and even non-euro-area countries such as Bulgaria. The second wave of institutionalisation has therefore taken place to install the European Central Bank as the single micro-prudential supervisor for key banks in the euro-area and banks in voluntarily participating countries outside of the euro area. This is for the purpose of severing the links between weak

\footnotetext{
${ }^{7}$ Iris $\mathrm{H}^{-} \mathrm{Y}$ Chiu, Regulatory Convergence in EU Securities Regulation (Kluwer Law International 2008).

${ }^{8}$ See account and analysis by Eddy Wymeersch, 'Europe's New Financial Regulatory Bodies' (2OII) II Journal of Corporate Law Studies 443.

${ }^{9}$ Mads Andenas and Iris $\mathrm{H}^{-} \mathrm{Y}$ Chiu, 'Financial Stability and Legal Integration in Financial Regulation' (2013) European Law Review 335.

ro European Parliament and Council Regulation (EU) I093/2010 of 24 November 2010 establishing a European Supervisory Authority (European Banking Authority), amending Decision No $7 \mathrm{I} 6 / 2009 / \mathrm{EC}$ and repealing Commission Decision 2009/78/EC [2010] OJ L331/12 (EBA Regulation 2010).

${ }^{\mathrm{II}}$ European Parliament and Council Regulation (EU) IO95/20IO of 24 November 2010 establishing a European Supervisory Authority (European Securities and Markets Authority), amending Decision No 716/2009/EC and repealing Commission Decision 2009/77/EC [2010] OJ L331/84 (ESMA Regulation 2010).

${ }_{12}$ European Parliament and Council Regulation (EU) IO94/2010 of 24 November 2010 establishing a European Supervisory Authority (European Insurance and Occupational Pensions Authority), amending Decision No 716/2009/EC and repealing Commission Decision 2009/79/EC [2OIO] OJ L331/48 (EIOPA Regulation 2OIO).

${ }^{13}$ European Parliament and Council Regulation (EU) I092/2010 of 24 November 2010 on European Union macro-prudential oversight of the financial system and establishing a European Systemic Risk Board [20IO] OJ L331/I (ESRB Regulation 20IO).
} 
sovereigns and national banks, ${ }^{14}$ so that confidence can be shored up against the relevant national banks that can be nursed and regulated back to health. The Single Supervisory Mechanism ${ }^{15}$ (SSM) is supported by the Single Resolution Mechanism (SRM) for the banks overseen in the SSM. The SRM has been developed alongside regulatory convergence in recovery and resolution frameworks for financial institutions. ${ }^{16}$ In sum, the regulatory architecture for financial services has undergone major overhaul since the onset of the global financial crisis $2008^{-} 9$. The first stage of the overhaul (at that time not seen as a first stage) came in the form of the ESFS in 20IO, and the second stage of the overhaul relating to the SSM in place from November 20I4. In view of the borderless nature of financial services and markets and the significant pan-European effects of financial fallouts, ${ }^{17}$ increased policy-making at the EU level is an inevitable development and the observed 'transference of powers to the EU' is a trajectory set to continue. Nevertheless, EU financial regulation is based on an 'intervention-based' model where much of day-to-day supervision is left to national regulators who are subject to European level purview. ${ }^{\text {I8 }}$ Although institutional reform at the EU level for regulating financial services is the accepted policy direction, reforms are inevitably viewed with some fear and suspicion as regulating financial services is a matter of political salience ${ }^{19}$ and of interest to EU political institutions, Member State governments and national regulators, the industry and various stakeholder groups. For example, the British attack on ESMA's power to adopt emergency measures under the EU Short-selling regulation ${ }^{20}$ partly reflects its interests in protecting the hedge fund industry which is sizeable in the UK financial services sector. Institutional reforms have thus been born out of much debate, controversy and compromises reflected in the designs relating to institutional power and accountability.

\footnotetext{
${ }_{4} 4$ "Eurozone Agrees Common Bank Supervisor", Financial Times (I3 Dec 2012). Kern Alexander, 'Bank Resolution and Recovery in the EU: Enhancing Banking Union?' (2013) I4 ERA Forum 8I.

${ }^{15}$ SSM Regulation ( $\left.\mathrm{n}_{3}\right)$.

${ }^{16}$ Regulation (EU) No 806/2014 of the European Parliament and of the Council of 15 July 2014 establishing uniform rules and a uniform procedure for the resolution of credit institutions and certain investment firms in the framework of a Single Resolution Mechanism and a Single Resolution Fund and amending Regulation (EU) No I093/2010 [2014] OJ L 225/I ('SRM Regulation').

${ }^{17}$ See discussion in Guido Ferranini and Luigi Chiarella, 'Common Banking Supervision in the Eurozone: Strengths and Weaknesses' (2013) at http://ssrn.com/abstract_id=2309897.

${ }^{18}$ Pierre Schammo, 'EU Day-to-Day Supervision or Intervention-Based Supervision: Which Way Forward for the European System of Financial Supervision?' (2O12) 32 OJLS 77I.

${ }^{19}$ Christel Koop, 'Explaining the Accountability of Independent Agencies: The Importance of Political Salience' (201I) 3I Journal of Public Policy 209.

${ }^{20}$ Case 270/12 United Kingdom v Parliament and Council (not yet published), supported in Jacques Pelkmans and Mara Simoncini, 'Mellowing Meroni: How ESMA Can Help Build the Single Market' CEPS Commentary, I8 February 2014.
} 


\section{An Outline of the Framework of the ESFS}

In the face of urgent need for reform in the immediate aftermath of the global financial crisis, the first stage of institutional reforms was based on formalising institutional structures that had already existed in a quasiindependent form. These structures were the 'Level Three' Committees i.e. the Committee of European Banking Supervisors (CEBS), the Committee of European Securities Regulators (CESR) and the Committee of European Insurance and Occupational Pensions Supervisors (CEIOPS) formed pursuant to the Lamfalussy recommendations of $200 \mathrm{I}$ to foster supervisory and regulatory convergence in the implementation of harmonised legal standards. ${ }^{2 \mathrm{I}}$ Level Three committees forged technical guidelines to assist in the consistent implementation of harmonised legal standards and to achieve consistency in supervisory techniques and styles. The Committees' technical guidelines were not binding, but the Committees' work provided a soft framework for regulatory convergence on the books as well as in practice. ${ }^{22}$ Furthermore, the Committees ${ }^{23}$ fostered comity and respect for peer pressure through mechanisms such as CESR's consolidated 'Questions and Answers' ${ }^{24}$ and informal mediation processes facilitated by CESR for national regulators. The formalisation of structures already in existence seemed less politically controversial (as the Committees have had an evolutionary history based on their intergovernmental nature) and represented a reform step that was imminently achievable and efficient.

The graduation of the three sectoral Level Three committees to independent agencies is a logical step to take in institutionalising EU financial regulation, although the sectoral approach to regulation has, especially in the US context, been criticised for its limitations, incompatibility with developments in the financial sector and perhaps incoherence. ${ }^{25}$ The EBA, ESMA and EIOPA are tasked with certain

\footnotetext{
${ }^{21}$ For example, see CESR, 'Which supervisory tools for the EU securities markets?' (25 October 2004) Preliminary Progress Report No $04^{-3} 33^{f}$ http://www.esma.europa.eu/system/files/o4-333f.pdf accessed I8 December 2012 ('Himalaya Report'), 5 .

${ }^{22}$ Iris $\mathrm{H}^{-} \mathrm{Y}$ Chiu, Regulatory Convergence in EU Securities Regulation (Kluwer Law International 2008), chs 2-5.

${ }^{23}$ Mark W Zacher and Brent A Simon, Governing Global Networks (CUP I996), I3-35, for a general discussion of regime theory; James N Rosenau and Ernst Otto Czempiel (eds), Governance Without Government: Order and Change in World Politics (CUP 1992, rep 2000), 219; Anne-Marie Slaughter, A New World Order (Princeton University Press 2004). These discussions shed light on the nature and dynamics of cooperation in networks that exert powerful and consensual governance without requiring statebased backing by sanctions.

${ }^{24}$ Majone has also argued that the platform for technical standards and developing technocracy finds less resistance to network cooperation and consensus. See Giandomenico Majone, Regulating Europe (Routledge 1996).

${ }^{25}$ See Jeremy W Markham, 'Super-Regulator: A Comparative Analysis of Securities and Derivatives Regulation in the US, UK and Japan' (2003) 28 Brooklyn Journal of International Law 319, E Wymeersch, The Structure of Financial Supervision in
} 
overall responsibilities for EU financial regulation, but they oversee national regulators and are not directly involved with regulated entities, which are still subject to national regulators. The three agencies have the continuing mandate of market integration and legal convergence, and protective objectives, such as systemic stability and consumer protection. The Regulations establishing the EBA, ESMA and EIOPA have mirror provisions on the roles, functions and powers of these bodies. ${ }^{26}$ In terms of furthering the market integration objective, these bodies have the power to recommend technical standards for uniform implementation of EU Directives in financial regulation and to issue binding guidelines on supervisory practices and standards. ${ }^{27}$

The three agencies are responsible for achieving market integration through supervisory convergence, based on common guidelines, ${ }^{28}$ and the monitoring of coherence in supervisory action. The three agencies, in forging supervisory convergence, have the power to facilitate the settling of disagreements between national regulators, or where conciliation fails, to impose a decision to resolve the disagreement. ${ }^{29}$ They are also responsible for establishing colleges of supervisors for joint supervision and stress testing of financial institutions, ${ }^{30}$ forging a common supervisory culture $^{3 \mathrm{I}}$ and conducting peer reviews of national regulators for convergence in supervisory measures. ${ }^{32}$

The three agencies have the mandate to take the lead on setting policies and standards in consumer financial protection ${ }^{33}$ and ensuring the

Europe: About Single, Twin Peaks and Multiple Financial Supervisors' at http://papers.ssrn.com/sol3/papers.cfm?abstract_id=946695; but see Joseph J Norton, 'Global Financial Sector Reform: The Single Financial Regulator Model Based on the United Kingdom FSA Experience--A Critical Reevaluation' (2005) 39 International Lawyer 15; Howell E Jackson, 'Regulation in a Multi-sectored Financial Services Industry' (1999) 77 Washington University Law Quarterly 319.

${ }^{26}$ See analysis in Niamh Moloney, 'The European Securities and Markets Authority and Institutional Design for the EU Financial Market - A Tale of Two Competences: Parts I and 2' (2OII) I2 European Business Organisation Review 43 and 178 respectively.

${ }^{27}$ EBA, ESMA and EIOPA Regulations, arts 8, IO, 15-16. However, the power to make such delegated legislation is revocable by the European Council and Parliament (see arts I2 and I3) and is subject to review by the Commission (art II). The substantive technical standards may also be vetted and objected to by the Commission (art I4), providing layers of checks and balances to the exercise of such legislative power. The status of successfully passed standards and guidelines are however binding on Member States and non-compliance would amount to a breach of Union law (art I7).

${ }^{28}$ EBA, ESMA and EIOPA Regulations, art I6.

${ }^{29}$ EBA, ESMA and EIOPA Regulations, arts I8, I9.

${ }^{30} \mathrm{EBA}, \mathrm{ESMA}$ and EIOPA Regulations, art $2 \mathrm{I}$.

${ }^{3 \mathrm{I}}$ EBA, ESMA and EIOPA Regulations, art 29.

${ }^{32}$ EBA, ESMA and EIOPA Regulations, art 30.

${ }^{33}$ EBA, ESMA and EIOPA Regulations, art 9. 
consistent application of financial guarantee schemes. ${ }^{34}$ They are also tasked to deal with systemic risk mitigation, ${ }^{35}$ provide support for the work of the ESRB and facilitate coordinated crisis management by national regulators.

The sectoral approach is arguably insufficient for dealing with panEuropean perspectives and cross-border issues. Pan-European solutions to banks which have extensive cross-border operations proved to be challenging in the crisis as national governments and regulators engaged in self-interested actions, some to a greater degree than others. ${ }^{36}$ Hence, there is a need for the institution of a European level architecture that is able to engage with pan-European perspectives and develop capacity to deal with problems of that scale. In the absence of a single financial services regulator and/or supervisor for the EU, the creation of the ESFS includes a Joint Committee of the three sectoral agencies that could provide joined-up perspectives in the financial sector. Further the Joint Committee and the three agencies would support the work of the European Systemic Risk Board (ESRB). The ESRB is the pan-European body that is tasked with macro-prudential oversight. ${ }^{37}$ It is a body with a governing Board ${ }^{38}$ independent of the European Central Bank but nevertheless nested within the European Central Bank. The ESRB has the power to collect and request information from the three European authorities mentioned above, from national central banks and from regulators ${ }^{39}$ in order to carry out its analytical responsibilities to determine whether systemic risk warnings should be sounded. The ESRB's role is to issue warnings and/or recommendations to the $\mathrm{EU}$ as a whole or to individual Member States or national regulators ${ }^{40}$ but these warnings and recommendations are not strictly binding. A number of commentators ${ }^{4 \mathrm{I}}$

\footnotetext{
${ }^{34}$ EBA, ESMA and EIOPA Regulations, art 26.

${ }^{35} \mathrm{EBA}, \mathrm{ESMA}$ and EIOPA Regulations, arts 22, 23, 32.

${ }^{36}$ For example, the German and British unilateral actions in freezing Icelandic banks' assets in their jurisdictions upon failure of those banks; the unilateral unlimited deposit guarantee offered by Ireland to save its banks, the national lines taken in the resolution of Fortis bank. Post-crisis pan-European solutions in the resolution of Dexia, Cyprus banks, Bankia and Banco Espirito Santo of Portugal have however been dovetailed into coordinated European resolutions. See Jean Pisani-Ferry and Andre' Sapir, 'Banking Crisis Management in the EU: An Early Assessment' (2010) Economic Policy 34I; Mark Rhinard, 'European Cooperation on Future Crises: Toward a Public Good' (2009) 26 Review of Policy Research 439; Joel P Trachtman, 'The International Law of Financial Crisis: Spillovers, Subsidiarity, Fragmentation and Cooperation' (2010) Journal of International Economic Law 719.

${ }^{37}$ ESRB Regulation, art 3.

${ }^{38}$ ESRB Regulation, art 6.

${ }^{39}$ ESRB Regulation, art 15.

${ }^{40}$ ESRB Regulation, art 16.

${ }^{4 \mathrm{I}}$ Eilis Ferran and Kern Alexander, 'Can Soft Law Bodies Be Effective? Soft Systemic Risk Oversight Bodies And The Special Case Of The European Systemic Risk Board' (2010) European Law Review 75I; Alexandra Hennessy, 'Redesigning Financial Supervision in the European Union' (EUSA conference, Boston, 3-6 March 20II).
} 
have noted that although the power of the ESRB is limited to such 'soft law' warnings, these measures are unlikely to be ignored. Indeed, they are likely to facilitate a form of economic governance that may be adapted to suit both boom and crisis times.

It is noteworthy that institutional reform did not go along the lines of creating one centralised financial regulator and/or supervisor for EU financial markets. ${ }^{42}$ Wymeersch ${ }^{43}$ opines that the creation of one single financial services regulator and/or supervisor would have entailed difficult political discussions about the structure, governance and location of the single integrated body. In fact, the creation of such a body may require Treaty change as it is unlikely that such a body could be founded upon the narrow Meroni doctrine. ${ }^{44}$ The ESFS is arguably the subject of painstaking design to ensure adequate constraints of power within the confines of the Meroni doctrine and multiple accountability channels. ${ }^{45}$ These aims have arguably been achieved in the institutional architecture of the ESFS, but this Section raises the questions of whether institutional effectiveness and autonomy have been traded off. This Section argues that the power and accountability structures have succeeded in bounding the ESFS within certain constraints, but may pose handicaps to institutional effectiveness.

\section{Critically Exploring the Complex Designs in Power and Accountability in the ESFS and Technocratic Effectiveness of the Institutions}

In view of the pan-European powers and responsibilities vested in the three agencies, a complex design of power and accountability structures has come about to ensure that the three agencies fall within appropriate parameters of political constraints. Commentators are of mixed opinions whether the three agencies should be regarded as 'powerful' agencies. One school of opinion views the three agencies as limited and constrained in power as (a) the agencies do not have law-making power as such; they assist the Commission in providing first drafts of supporting technical standards to primary legislation; (b) they largely do not have direct relationships with regulated entities, except in the case of credit rating agencies and central counterparties under the purview of ESMA; (c) they rely on national

\footnotetext{
${ }^{42}$ See M Andenas, 'Who is Going to Supervise Europe's Financial Markets?' in M Andenas and Y Avgerinos (eds), Financial Markets in Europe - Towards a Single Regulator? (Kluwer Law International 2003) at Xv.

${ }^{43}$ Eddy Wymeersch, 'The Inst Itutional Reforms of the European Financial Supervisory System, An Interim Report' (2010) at http://ssrn.com/abstract=1541968.

${ }^{44}$ Case 9/56 Meroni v High Authority [1957-58] ECR 133 which provides that EU institutions can only delegate well-defined executive powers but not broad discretionary powers. This has lasting implications for the creation of EU agencies, and the Commission's White Paper on European Governance (200I) arguably reinforces the need for technocratic expert-led independent European agencies with specific powers to implement policies made by the Commission and take individual decisions pursuant to those policies but not to have broad regulatory powers.

${ }^{45}$ Herwig CH Hofmann, 'Agency Design in the European Union' (20II) at http://ssrn.com/abstract=I82323I.
} 
regulators to implement and enforce regulatory rules and in the collection of information; $;^{46}$ and (d) even in emergency situations where they wish to exercise the power to address a specific decision to a regulated entity, the approval of the European Council needs to be sought. Other commentators however view the three agencies as immensely powerful as they have quasi-regulatory powers distinguishing them from the other established types of agencies in the EU that are advisory in nature or implementers of policy without own discretion. ${ }^{47}$ In particular the three agencies are powerful as supranational supervisors of national regulators in terms of imposing implementing standards for regulation, supervisory convergence, settlement of disputes and mandating information conveyance. ESMA uniquely enjoys direct regulatory powers over credit rating agencies although specific powers and enforcement actions are set out in such a way as to meet the Meroni constraints against delegating broad discretionary powers. ${ }^{48}$

The diverging perspectives on the three agencies' powers possibly reflect a general uncertainty towards their position in the regulatory space. Such uncertainty has arguably arisen due to the complex arrangements over decision-making. The complexity is due to the need to keep within the Meroni parameters while effectively empowering the agencies to carry out tasks appropriate for their technocratic expertise. Thus, on the one hand, the agencies are regarded as 'powerful' in light of the loss of regulatory discretion on the part of national regulators in terms of policy and law making and supervisory practices. On the other hand, the agencies may not be regarded as 'powerful' because many of their key responsibilities are not undertaken independently, such as developing regulatory standards and addressing emergency decisions. Both perspectives of the agencies are valid if the agencies are looked at as bound up with the EU political institutions, particularly the Commission. ${ }^{49}$ The agencies could be viewed as extensions of ever-increasingly EU political power while not being autonomously powerful themselves.

\footnotetext{
${ }^{46}$ Elaine Fahey, 'Does the Emperor Have Financial Crisis Clothes? Re£ections on the Legal Basis of the European Banking Authority' (201I) 74 Modern Law Review 581; Nicolette Kost de Sevres and Lorenzo Sasso, 'The New European Financial Markets Legal Framework: A Real Improvement? An Analysis of Financial Law and Governance in European Capital Markets from a Micro and Macro economic Perspective' (201I) Capital Markets Law Journal 30.

${ }^{47}$ Pierre Schammo, 'The European Securities and Markets Authority: Lifting the Veil on the Allocation of Powers' (20II) 48 Common Market Law Review I879; Michelle Everson, 'A Technology of Expertise: EU Financial Services Agencies' (June 20I2) LSE Research Paper; Pablo Iglesias-Rodriguez, The Accountability of Financial Regulators (Wolters Kluwer 2014).

${ }^{48}$ Niamh Moloney, 'Reform or Revolution? The Financial Crisis, EU Financial Markets Law, and the European Securities and Markets Authority' (20II) 6o ICLQ $52 \mathrm{I}$.

${ }^{49}$ Noted in DG for Internal Policies, Parliament's Reviere of the ESFS (2013) as many stakeholders' views.
} 
The complexity in the design of power structures is due to a preoccupation with keeping within the Meroni parameters, and with ensuring that accountability mechanisms are constructed comprehensively in order to dispel fears and suspicions against the three new agencies. In this process, the independence of the agencies which is an important attribute towards effectiveness seems relatively neglected..$^{50}$ The independence of these technocratic and expert-led agencies is a key attribute believed by the European Parliament ${ }^{5 \mathrm{I}}$ to be important for sound financial regulation in the EU, un-entangled from political interests and regulatory capture. In general, commentators support the independence of agencies as agencification is intended to achieve the purposes of de-politicisation and the forging of technocratic and objective solutions to regulatory issues. ${ }^{52}$ The roles of the three agencies could indeed provide a mediating platform between political and national interests given their inter-governmental background, and yet forge an objective and expert-led position on the final shape of policy and regulation. ${ }^{53}$ This article notes Everson's concerns ${ }^{54}$ for excessive de-politicisation of policy-making in financial regulation by framing these issues as subject to technocratic regulation, but is more optimistic about the three agencies' roles. This article is of the view that the three agencies can act as suitable platforms to mediate the technocratic aspects of financial regulation and the more politicallycharged aspects. The UK and Germany's responses to the Icelandic bank failures in 2009 for example, have demonstrated the precedence of politically-charged actions over technocratically efficient solutions. Hence, there may be a case for arguing the contrary to Everson's concerns - that

\footnotetext{
${ }^{50}$ Although the agencies are tasked to act independently, EBA, ESMA and EIOPA Regulations, art I, and national regulator representatives, the Chairperson of the governing body, the Board of Supervisors and the Executive Director of the administrative organ, the Management Board, are tasked to exercise their judgment independently of political and national interests, arts 42, 46, 49 and 5I, the Regulations feature overwhelmingly substantive provisions on control and accountability that may affect independence.

${ }^{51}$ DG for Internal Policies, Parliament's Review of the ESFS (2013); Pablo IglesiasRodriguez, The Accountability of Financial Regulators (Wolters Kluwer 2014), 217.

${ }^{52}$ Madalina Busuioc and Martijn Groenleer, 'The Theory and Practice of EU Agency Autonomy and Accountability: Early Day Expectations, Today's Realities and Future Perspectives' in M Everson, C Monda and E Vos (eds), European Agencies in between Institutions and Member States (Kluwer Law International 20I4 forthcoming); Damien Geradin, 'The Development of European Regulatory Agencies: What the EU Should Learn from American Experience' (2004) II Columbia Journal of European Law I.

${ }^{53}$ One notes Everson's critique of this position as technocratisation could be a way to evade addressing the political nature of some issues and hence mute the voices concerned with political implications, see Michelle Everson, 'A Technology of Expertise: EU Financial Services Agencies' (June 2012) LSE Research Paper.

${ }^{54} \mathrm{It}$ is noted that Everson warns against de-politicisation of issues in the EU by technocratisation of these as regulatory areas. She is sceptical of the effectiveness of such an approach and the is concerned for the marginalisation of democratic voice in policy-making, see Michelle Everson, 'A Technology of Expertise: EU Financial Services Agencies ‘ (June 2012) LSE Research Paper.
} 
there is a need to de-politicise policy-making in financial services regulation.

The path towards achieving greater de-politicisation and technocratisation of financial regulation involves the recalibration of the political hold over financial regulation itself. The design of the three agencies' power and accountability structures thus reflects this challenge, and has resulted in the institution of significant controls on the three agencies' exercise of powers. The author of this article is of the view that policy-makers have become too pre-occupied with designing appropriate controls to the extent of insufficient consideration for the importance of the independence of the three agencies for the purposes of their technocratic effectiveness. This Section will argue that although the three agencies are subject to extensive channels of political and stakeholder accountability in their exercise of powers, designed to please the relevant constituents who are concerned with the powers vested in the agencies, these mechanisms could pose handicaps to supporting the development of technocratic and objective work on their part. Some of these mechanisms are more in the nature of 'control' mechanisms directly cutting down the level of autonomy the agencies could enjoy.

In terms of control, certain EU political institutions have rights of control over the agencies' decisions, such as Commission's final say on draft technical standards $s^{55}$ and implementing technical standards ${ }^{56}$ submitted by the three agencies as part of their work in developing the single rulebook, the Council's power to revoke a decision addressed by the three agencies to Member State regulators, ${ }^{57}$ the Council's power to determine whether an emergency situation has arisen for the three agencies to take particular decisions addressed to specific financial institutions, ${ }^{8}$ and the Commission's oversight of the three agencies' budgets ${ }^{59}$ and staff employment policies. ${ }^{60}$ The Commission has the power to review the delegated power to the three agencies in drafting technical standards and may recommend extension of such delegation. The Council or Parliament may exercise the power to revoke such delegation. ${ }^{6}$ The power of EU political institutions to instruct the three agencies to undertake certain tasks is also a form of control over the agencies' powers. For example, the Parliament, Council or Commission could ask the agencies for advisory opinions on any matter of their competence, ${ }^{62}$ the Commission could issue an opinion on a Member State's breach of Union law and ask the agencies

\footnotetext{
${ }^{55}$ EBA, ESMA and EIOPA Regulations, art Io.

${ }_{56}^{6}$ ibid, art 15.

57 ibid, art 38.

${ }^{58}$ ibid, art I8.

${ }^{59} \mathrm{ibid}$, arts $63-65$.

${ }^{60}$ ibid, art 68.

${ }^{61}$ ibid art II, I2.

${ }^{62}$ ibid art 34.
} 
to address decisions directly to financial institutions concerned, ${ }^{63}$ and the ESRB could ask the agencies for information to assist in its systemic risk oversight. ${ }^{64}$

In terms of political accountability, the three agencies are subject to ex ante forms of accountability such as Commission representation on the governing body, the Board of Supervisors, albeit in non-voting capacity. The governing body is dominated by Member State regulators alongside non-voting representatives from the Commission, ECB, ESRB and the other ESAs. ${ }^{65}$ Furthermore, the European Parliament has the power to veto the appointment of the Chairperson of the Board of Supervisors, ${ }^{66}$ and its approval is required for the appointment of the Executive Director $^{67}$ of the Management Board, which is the administrative organ of the agencies supporting the work of the Board of Supervisors.

The three agencies are also subject to extensive reporting accountability to the EU political institutions in respect of certain decisions. Although such reporting may be carried out after the decision is taken, it is unclear if such reporting is ex post for information only or whether intervention may indeed be carried out by the political institutions. For example, where the three agencies consider that there is a need to restrict or prohibit certain types of financial activity, such as short-selling to preserve the financial stability of the EU, the Commission needs to be informed in order 'to facilitate the adoption of any such prohibition or restriction'. ${ }^{68}$ It is not clear if the Commission has the final say, but it would seem that the Commission's acquiescence is a pre-condition to such a decision made by the agencies, and the legislative wording suggests Commission control rather than ex post accountability to the Commission. The three agencies also need to inform the Commission, Council and Parliament of the informal guidelines and recommendations they issue to Member State regulators, ${ }^{69}$ report on market developments, risks, trends and vulnerabilities twice a year to the Commission, Parliament and Council, ${ }^{70}$ submit annual work programmes ${ }^{71}$ and annual reports ${ }^{72}$ to the Commission, Parliament and Council. The Parliament or Council could also invite the Chairpersons of the agencies to appear in person to answer any questions. ${ }^{73}$

\footnotetext{
${ }^{63}$ ibid, art 17.

${ }^{64} \mathrm{ibid}$, art 36. The agencies are tasked with the general role of developing systemic risk indicators and stress testing regimes in order to assist the ESRB in its systemic risk oversight, see arts $22-23$.

${ }^{65}$ ibid, art 40.

${ }^{66}$ ibide, art 48 .

${ }^{67}$ ibid, art $5 \mathrm{I}$.

${ }^{68}$ ibid, art 9.

${ }^{69}$ ibid, art 16.

${ }^{70}$ ibidarts 23 and 33 .

${ }^{71}$ ibid, art 43.

${ }^{72}$ ibid, art 44 .

${ }^{73}$ ibid, art 50.
} 
The control and accountability channels designed for the three agencies are rather extensive in nature, and the agencies really only have their own discretion in the areas of supervisory convergence, ${ }^{74}$ settlement of disagreements between national regulators, ${ }^{75}$ and to certain extent, work undertaken in the Joint Committee. ${ }^{76}$ Although the Commission is represented at Joint Committee meetings, it is less certain how much influence and control such a representative has, and it is noted that the Joint Committee establishes it own sub-committees and decision-making procedures. Iglesias-Rodriguez ${ }^{77}$ considers the main accountability mechanisms for the three agencies to lie in political accountability and control. Political accountability and control meet the immediate need of supporting the legitimacy of the three agencies. However, the longer term effects on the autonomy and technocratic leadership of the agencies need to be considered. ${ }^{78}$

The power, control and accountability structures discussed so far are premised on a need to usher in the institution of financial regulation in the EU within politically acceptable parameters for the EU political institutions and Member States. The author of this article is of the view that the autonomy, independence and technocratic leadership of the agencies, although formally endorsed, are relatively more neglected attributes, and could be undermined by the extensive control and accountability mechanisms. Commentators argue that accountability is not contrary to independence ${ }^{79}$ as independence gives rise to accountability for legitimacy purposes, and the lack of independence makes accountability an irrelevant issue. In the context of the three agencies however, the features of control discussed above are relatively extensive and should give rise to concerns as to the extent of independence really enjoyed by the agencies. The above has also discussed the nebulous nature

\footnotetext{
${ }^{74}$ ibid, arts 2I, 29-3I.

${ }^{75}$ ibid, arts $19^{-20}$. Even then such needs to be reported to Parliament in annual reports, but annual reporting is routinely received by the Parliament in relation to so many agencies in the EU that Curtin argues that such a form of accountability does not particularly attract scrutiny, see Dierdre Curtin, 'Delegation to EU Non Majoritarian Agencies and Emerging Practices of Public Accountability' in Regulation through Agencies: A New Paradigm of European Governance 87 (2005) at http://ssrn.com/abstract=I34977I.

${ }^{76}$ EBA, ESMA and EIOPA Regulations, arts 54-56.

${ }^{77}$ Pablo Iglesias-Rodriguez, The Accountability of Financial Regulators (Wolters Kluwer $2014)$, ch 6.

${ }^{78}$ ibid 24I.

${ }^{79}$ Madalina Busuioc and Martijn Groenleer, 'The Theory and Practice of EU Agency Autonomy and Accountability: Early Day Expectations, Today's Realities and Future Perspectives' in M Everson, C Monda and E Vos (eds), European Agencies in between Institutions and Member States (Kluwer Law International 2014 forthcoming); Eva Hüpkes, Marc Quintyn and Michael Taylor, 'Accountability Arrangements for Financial Sector Regulators' (IMF Economic Issues 2006) via http://www.imf.org/external/pubs/ft/issues/issues39/ei39.pdf.
} 
of ex ante forms of political accountability which could act as 'controls'. It may be argued that such control is necessary as falling within Meroni parameters, as the agencies cannot have law-making powers and are not in a position to determine breach of Union law. However, one queries why implementing technical standards that involve no strategic decision cannot be decided independently by the agencies, why the agencies should be subject to a threat of revocation in their standard-setting roles and why annual work programmes have to receive ex ante approval from political institutions? In other words, the article doubts that the extent of control, or control in the form of ex ante accountability, gives proportionate importance to the autonomy, independence and technocratic leadership of the agencies.

The three agencies are also subject to accountability in terms of the reviewability of their decisions. Any natural or legal person including national regulators to whom a binding agency decision is addressed may appeal to the Board of Appeal constituted jointly by the three agencies. ${ }^{80}$ The three agencies would appoint, from a Commission shortlist, four representatives each (two members and two alternates) from their Management Boards to sit on the Board of Appeal alongside other experts openly recruited. ${ }^{8 \mathrm{I}}$ The Board of Appeal would consist of 6 members and 6 alternates and every member is expected to act impartially and independently in deciding any appeal, with interested members refraining from sitting on the appeal. ${ }^{82}$ The Board of Appeal is required to provide resolution in an expeditious manner ${ }^{83}$ and is also required to make its procedures and its reasoned decisions public. ${ }^{84}$ The Board's decisions are subject to appeal to the European Court of Justice and access to the Court is also available under Art 263 of the Treaty of the European Union where an Authority's decision cannot be appealed ${ }^{85}$ to the Board of Appeal. ${ }^{86}$

The three agencies are also subject to stakeholder accountability. The agencies are mandated to set up Stakeholder Groups of 30 individuals each, ${ }^{87}$ represented by the industry, users of financial services, employees' representatives, consumers and at least five top-ranking academics in the field. These stakeholder groups are consulted upon in the processes leading up to drafting technical standards, implementing technical

\footnotetext{
${ }^{80}$ EBA, ESMA and EIOPA Regulations, art 60.

${ }^{8 \mathrm{r}}$ ibid, art 58 .

${ }^{82}$ ibid, arts 58 and 59 .

${ }^{83}$ Within two months of lodging an appeal.

${ }^{84}$ EBA, ESMA and EIOPA Regulations, art 60.

${ }^{85} \mathrm{ibid}$, art 6r.

${ }^{86}$ However, Pieter Van Cleynenbreugel, 'Judicial Protection against EU Financial Supervisory Authorities in the Wake of Regulatory Reform' (2012) at http://ssrn.com/abstract $=2194172$ criticises that the judicial accountability is too narrow as being confined to persons directly affected by agency decisions and that the grounds in Art 263 may not encompass all possible grievances against the agencies.

${ }^{87}$ EBA, ESMA and EIOPA Regulations, art 37.
} 
standards, and guidelines and recommendations, providing a form of input legitimacy to the agencies' responsibilities. Iglesias-Rodriguez ${ }^{88}$ however notes that stakeholder groups tend to be industry-dominated and not wellrepresented by consumer groups. At the moment no signs of regulatory capture have emerged in relation to industry participation in the agencies' deliberations and in fact the Parliament review of the ESAs suggests that the ESAs have been taking care to refrain from being overly engaged with stakeholders. ${ }^{89}$

Where the ESRB is concerned, although its powers are non-binding in nature, it is subject to extensive input legitimacy mechanisms in terms of its accountability structure. Its General Board will be assisted by a Steering Committee $^{90}$ made up of an even spread of representatives from the ESRB, the European Central Bank, the ESMA, EBA and EIOPA, the European Commission, the Economic and Financial Committee of the European Council, and the two advisory committees of the ESRB. The ESRB's work will be assisted by an Advisory Scientific Committee ${ }^{9 \mathrm{I}}$ which comprises of experts from across a wide range of fields and skills and the Advisory Technical Committee ${ }^{92}$ which consists of representatives from national central banks and EU-level representation. The representation feeding into the ESRB's decision-making includes EU-level political interests, national interests as well as technocratic expertise. The design for representation internalises any potential contests between EU-level and national objectives, as well as political and technocratic objectives under the ESRB. However, this complex representation structure does in itself promise that effective mediation of contests of interests.

In sum, the ESFS may appear to be an institutional set-up that is powerful and autonomous, but is actually underpinned by extensive intergovernmentalism and controls by EU political institutions. The challenge for the ESFS is arguably to establish its identity and credibility in EU financial services regulation, and such a challenge may become more acute with the advent of the SSM that brings about a differentiated form of supervision for certain euro-area banks.

The article argues that the very complexity of design in the ESFS could be used to overcome the weakness discussed above. The ESFS could leverage upon its inter-agency features to boost its autonomy, independence and credibility in becoming a technocratic, expert-led system for EU financial services regulation. The advantage of not being a single financial services regulatory institution is that the sectoral boundaries separating the

\footnotetext{
${ }^{88}$ Pablo Iglesias-Rodriguez, The Accountability of Financial Regulators (Wolters Kluwer 20I4), ch 7 .

${ }^{89}$ DG for Internal Policies, Parliament's Review of the ESFS (2013).

${ }^{90}$ ESRB Regulation, art II.

${ }^{91}$ ibid, art $\mathrm{I} 2$.

${ }^{92}$ ibid, art 13 .
} 
agencies promote non-homogenous approaches while inter-agency coordination and interactions foster crucial joined-up thinking. Interagency coordination can be fostered for holistic perspectives in financial regulation, and develop the technocratic competence and credibility of individual institutions, overcoming the limitations that agencies face in view of controls over power. Over time, a sustained pattern of inter-agency coordination can even develop forms of inter-agency accountability that could be important in underlining the agencies' legitimacy. The development of inter-agency accountability can even go towards reducing the need for extensive political controls over agencies.

Part III will now go on to explore the inter-agency coordination of the three agencies in the Joint Committee and the Board of Appeal. Part III will discuss how inter-agency learning and coordination is developing in the ESFS and how such can help secure agency technocratic credibility and improve agency autonomy and independence at the same time. The potential for development of inter-agency accountability will also be highlighted.

\section{INTER-AGENCY LEARNING, COORDINATION, ACCOUNTABILITY AND ACHIEVEMENTS}

This Part argues that the three agencies EBA, ESMA and EIOPA have not merely succumbed to the limitations in their power structures and accountability mechanisms in carrying out their mandates. They have taken steps to develop those areas of their responsibilities where they may act relatively more independently, such as in consumer protection, ${ }^{93}$ and are developing their technocratic credibility as autonomous agencies in EU financial regulation. ${ }^{94}$ In particular, the article argues that the three agencies are augmenting their fields of independence by developing expertise in areas under the purview of the Joint Committee. Inter-agency coordination has arguably provided a platform for increased learning, accountability and fostering of independence of the agencies as technocratic expert-led outfits. This is a form of inter-dependence that reinforces the three agencies' scope of work and the development of their technocratic expertise. Such inter-dependence boosts the autonomy, independence and technocratic leadership of each agency, and also has the potential of enhancing accountability through inter-agency transparency

\footnotetext{
${ }^{93}$ As commended by the European Commission's review of the ESFS, see European Commission, Report from the Commission to the European Parliament and the Council on the operation of the European Supervisory Authorities (ESAs) and the European System of Financial Supervision (ESFS) (7 August 2014).

${ }^{94}$ Observed by stakeholders in DG for Internal Policies, Parliament's Review of the ESFS (2013), and also commended in European Commission, Report from the Commission to the European Parliament and the Council on the operation of the European Supervisory Authorities (ESAs) and the European System of Financial Supervision (ESFS) 7 August 20I4).
} 
and coordination. This Part explores the dynamics and achievements of such inter-agency learning and accountability.

\section{Foint Committee}

The Joint Committee of the three agencies is to comprise of the Chairpersons of each agency and the Executive Directors of each agency, a representative from the Commission and ESRB respectively, who would be observers at the meetings. ${ }^{95}$ The Joint Committee is established to ensure cooperation and cross-sectoral consistency in policy areas such as financial conglomerates, accounting and auditing, micro-prudential analyses of cross-sectoral developments, risks and vulnerabilities for financial stability, retail investment products, measures combating money laundering, and information exchange with the ESRB and developing the relationship between the ESRB and the agencies. ${ }^{96}$ In particular, the Joint Committee may establish sub-committees dedicated to technocratic leadership in the above areas, but a mandatory sub-committee on Financial Conglomerates must be established. ${ }^{97}$ The Joint Committee is also the forum for joint decisions and positions to be adopted among the three agencies. ${ }^{98}$

This Section argues that the Joint Committee has developed to be a platform for the three agencies to develop inter-agency coordination and learning that further enhances each agency's autonomy, independence and technocratic leadership. Furthermore, inter-agency interactions promote transparency between the agencies. Although such transparency is not necessarily publicly visible, such interactions can promote enhanced accountability for each agency's technocratic development and performance. This Part will mention a few examples gathered from the publicly available documents of the Joint Committee, although a comprehensive trawl and analysis of all Joint Committee documents has not been conducted for the purposes of this article.

First, the Joint Committee has established a procedure of decision-making that involves consensus of the three Chairpersons. ${ }^{99}$ Disagreements would result in reconsiderations of issues which would then be subject to decision-making again. This procedure fosters inter-agency transparency, sharing, learning and negotiation and can contribute towards enhancing the technocratic development in each agency. The coordination and interaction between the agencies pursuant to Joint Committee work has

\footnotetext{
${ }^{95}$ EBA, ESMA and EIOPA Regulations, art 55.

${ }^{96}$ ibid, art 54.

${ }^{97}$ ibid, art 57.

${ }_{98}^{8}$ ibid, art 56.

${ }^{99}$ Decision of the Joint Committee of the European Banking Authority, European Insurance and Occupational Pensions Authority, and European Securities and Markets Authority adopting the Rules of Procedure of the Joint Committee of the European Supervisory Authorities (2I June 20II).
} 
led to greater cross-sectoral training that could enhance each agency's technocratic expertise. ${ }^{\text {IOO }}$

Next, the three agencies have established increased numbers of subcommittees under the purview of the Joint Committee, suggesting that they are increasingly taking a stake in providing technocratic leadership in policy development, and not merely doing the minimal to cooperate in the matters set out in their instituting legislations. Besides the mandatory Financial Conglomerates sub-committee, the Joint Committee established a sub-committee on Cross-sectoral Developments, Risks and Vulnerabilities, a sub-committee on Money Laundering, a sub-committee on Consumer Protection and Financial Innovation, which has formed three sub-groups to deal specifically with cross-selling and complaintshandling, ${ }^{\text {IOI }}$ product governance and oversight and draft technical standards for packaged retail investor products (PRIPs). ${ }^{102}$ The subcommittee on Financial Conglomerates has championed ${ }^{103}$ for wider supervisory remit over groups of financial institutions that may pose crosssectoral and systemic risks, positioning its technocratic leadership on one of the Joint Committee's fundamental remits. It has also developed standards for supervisory convergence in the oversight of financial conglomerates. ${ }^{\mathrm{IO}} 4$ The sub-committee on Cross-sectoral Developments, Risks and Vulnerabilities is responsible for delivering the bi-annual report on cross-sectoral market developments, risks and vulnerabilities in the EU which the three agencies are tasked to prepare for the Commission, Parliament and Council. The Joint Committee notes its increasing expertise as a risk intelligence gatherer and monitor, and the usefulness of the reports feeding into the Council's ECOFIN Financial Stability Table. ${ }^{\text {IO5 }}$

roo Joint Committee Work Programme (2013) at http://www.esma.europa.eu/sk/system/files/jc-2013-oo2.pdf; and Joint Committee Work Programme 20I4, via http://www.esma.europa.eu/sk/system/files/jc-20I405I_20I4_work_programme_of_the_joint_committee_of_the_esas.pdf.

${ }^{\text {Ior }}$ See Joint Committee, foint Committee Consultation Paper on Guidelines for CrossSelling Practices (22 December 2014) at http://www.esma.europa.eu/system/files/jc_cp_2OI4_05_consultation_paper_on_cross _selling.pdf.

Io2 Joint Committee Work Programme 2013 at http://www.esma.europa.eu/sk/system/files/jc-2013-002.pdf.

${ }^{103}$ EBA, EIOPA and ESMA's Response to the European Commission's Call for Advice on the Fundamental Reviere of the Financial Conglomerates Directive (2012) at http://www.esma.europa.eu/sk/system/files/jc_2OI2_88.pdf;

${ }^{104}$ Joint Committee, Joint Guidelines on the Convergence of Supervisory Practices Relating to the Consistency of Supervisory Coordination Arrangements for Financial Conglomerates (22 December 2014$)$ at http://www.esma.europa.eu/system/files/jc_gl_2OI4_oI_joint_guidelines_on_coordinat ion_arrangements_for_financial_conglomerates.pdf.

ro5 Joint Committee Work Programme 2014, at http://www.esma.europa.eu/sk/system/files/jc-2OI405I_20I4_work_programme_of_the_joint_committee_of_the_esas.pdf. 
This Section also observes that significant strides have been taken by the Joint Committee in consumer protection, and these establish the technocratic expertise of all three agencies in developing EU-wide standards in leading consumer protection agendas and policies. The Parliamentary review ${ }^{106}$ of the agencies has pointed out that the EBA is relatively weaker than ESMA in developing consumer protection thinking, but the work in the Joint Committee has facilitated inter-agency learning in this regard. The Joint Consumer day in $2014{ }^{107}$ allows inter-agency crossfertilisation of ideas and exchange with stakeholders too. EIOPA has also significantly benefited from ESMA's leadership in consumer protection thinking and policy development. ${ }^{108}$ ESMA's and EIOPA's annual reports in $2013^{109}$ for example reflect a largely similar position on focusing on improving consumer protection in retail financial services. Furthermore, the EBA and ESMA have also learnt from EIOPA in developing a common consumer complaint-handling policy ${ }^{\mathrm{IIO}}$ which is relevant across the sectors due to cross-selling activities in the financial sector.

The three agencies are also taking technocratic leadership on new issues that have arisen in the regulatory sphere that are cross-sectoral in nature although not specifically mandated in the instituting legislations, such as in reviewing mechanistic reliance on credit ratings, ${ }^{\text {III }}$ and the review of benchmark setting and regulation of the relevant processes. ${ }^{112}$ In particular, in the review of mechanistic reliance on credit ratings, the three agencies have laid down in a single comparable document references in rules and guidelines under their respective purview which could be a form of mechanistic reliance on credit ratings. This tabling and comparative approach forces each agency to consider objectively the purpose and consequences of the relevant rules and guidelines in order to determine the best way forward. The agencies have noted learning from ESMA in the process, as ESMA provides for discretion to be exercised on the part of the regulated entities to consider the impact of rating changes and therefore does not mandate a mechanistic approach. ${ }^{\mathrm{II3}}$

Although these developments are rather specific in nature, one notes that the Joint Committee has pursued technocratic leadership eagerly within its express remit and beyond, where new issues arise. Such inter-agency

\footnotetext{
${ }^{106}$ DG for Internal Policies, Parliament's Review of the ESFS (2013).

${ }^{107}$ Joint ESAs consumer protection day 4 June 2014.

${ }^{108}$ Discussed in relation to consumer protection day, above.

${ }^{109}$ ESMA Annual Report 2013, EIOPA Annual Report 2013.

${ }^{110}$ Joint Committee, Final Report on Guidelines for Complaints-handling for the Securities (ESMA) and Banking (EBA) sectors, and CP (November 2013).

${ }^{\mathrm{III}}$ Joint Consultation Paper on Mechanistic References to Credit Ratings (November 2013), Final Report (February 20I4).

${ }^{112}$ Joint Committee, Letter on Possible Framework for the Regulation of the Production and Use of Indices Serving as Benchmarks in Financial and other Contracts (November 2013).

${ }^{113}$ Foint Consultation Paper on Mechanistic References to Credit Ratings Final Report (Feb 20I4).
} 
coordination has fed into the technocratic development of each agency, such as the EBA and EIOPA in consumer protection, ESMA in financial stability oversight, overall strengthening the autonomy and effectiveness of each agency. II4 Furthermore, inter-agency coordination compels transparency, sharing and learning amongst agencies and such can add to inter-agency accountability which supports the autonomy and technocratic effectiveness of the agencies. Inter-agency accountability would serve a different purpose from the political and stakeholder channels of accountability that serve the purposes of 'perception legitimacy'. Interagency accountability can be a promising development in improving agency effectiveness in terms of autonomous and objective decision-making in technocratic expertise that is depoliticised and neutral.

\section{Inter-agency Learning and the Board of Appeal}

The Board of Appeal is also a forum for inter-agency learning to take place, and this article argues that the three decisions that have been issued by the Board to date provide many constructive points of feedback and learning for the three agencies. Inter-agency coordination on the Board provides opportunities for scrutiny into agency processes and practices and constitutes a form of inter-agency accountability which is also available for public scrutiny. The author is not aware of any appeal to the CJEU against the Board of Appeal's decisions yet, but any such appeal would also provide learning opportunities not only for the agencies but also for inter-agency coordination and accountability.

The first decision concerns the complaint made by SV Capital Oü against the EBA. ${ }^{115}$ In this case, SV Capital had been assigned a claim by Instmark Oü which raised a matter to the EBA regarding the suitability of persons directing the Estonian branches of Finnish Bank Nordea in Estonia. The original claimant operated a current account at a Nordea branch in Estonia which was frozen due to money laundering concerns. The Estonian court subsequently decided that the action taken by Nordea was illegal and that the declarations made by two governors of the Nordea branch regarding the non-existence of certain documents between Instmark and Nordea were untrue. SV Capital raised a concern to the Estonian financial regulator that the two governors of the Nordea branch ought to be removed if their credibility had been doubted in court. The Estonian authority directed SV Capital to the Finnish home authority with supervisory powers and jurisdiction over the Nordea branch. The Finnish home authority rejected SV Capital's complaint. SV Capital brought the matter to the EBA to allege that the Finnish authority had breached

\footnotetext{
${ }^{114}$ Inter-agency learning is still nevertheless in an early stage as the Parliamentary review notes that the EBA and EIOPA are inundated with their respective draft technical standards work in micro-prudential regulation and Solvency II respectively and EBA's stress testing developments have also pre-occupied the EBA significantly. See DG for Internal Policies, Parliament's Review of the ESFS (2013).

${ }^{115}$ Decision of the Board of Appeal in SV Capital Oü v EBA (Frankfurt, 24 June 2013).
} 
Union law by not removing unsuitable persons from directing the Nordea branch in Estonia. The EBA's response was not to take the matter further as it regarded itself as having no jurisdiction to intervene in matters of corporate governance other than in the parent credit institution. On appeal to the Board of Appeal, the Board considered that the EBA had interpreted its remit too narrowly and that the EBA could intervene in matters regarding the corporate governance of key branches such as the Estonian branch of Nordea, in relation to key function holders that could include persons directing the branches. The matter was remitted to the EBA. However, the EBA ultimately decided not to investigate into the matter as a breach of Union law as it considered the Finnish regulator's explanation that the two persons concerned were not key function holders in the branch to be adequate. SV Capital raised an appeal to the Board regarding the EBA's decision, alleging that the EBA refused to investigate the matter due to its fears of damaging relations with national regulators, that it was not pursuing its responsibilities robustly, and that the EBA should always prefer to investigate than otherwise. The Board of Appeal reviewed the EBA's decision and was of the view that the decision not to investigate was based on a reasoned reliance on the Finnish home authority's assessment of the importance or otherwise of the two persons to the Estonian branch. ${ }^{\mathrm{II}}{ }^{16}$ The conclusion made that those two were not key function holders was one that could be upheld by the EBA and the Board did not find blind reliance or a less than robust culture at the EBA dealing with national regulators.

The two appeals brought by SV Capital against the EBA provided opportunities for high level scrutiny of the EBA's understanding of its remit, its relations with national regulators and the division of regulatory responsibilities between them. The first case demonstrated the EBA's tentativeness in assuming a wide remit and this may highlight the hesitation experienced in the first steps of a new agency. The conclusion made by the Board of Appeal in interpreting the EBA's remit in overseeing corporate governance matters is important in consolidating the identity of the EBA and its understanding of its scope of responsibilities and powers. Furthermore, the Board of Appeals' scrutiny into the EBA's rationale for its decision not to investigate and its decision-making processes helps the EBA in consolidating its independent decision-making capacity, neither to be captured by national regulators nor to be compelled by the industry.

The second appeal ${ }^{117}$ is in relation to ESMA's decision not to register a Ukrainian credit rating agency incorporated in the UK as an authorised credit ratings provider that could disseminate ratings in the EU. Global Private Ratings Company 'Standard Rating' Ltd (GPRC) was suspected by the UK Financial Services Authority to be undertaking credit rating

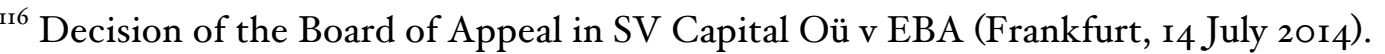
${ }^{117}$ Decision of the Board of Appeal in Global Private Rating Company 'Standard Rating' Ltd v ESMA (Frankfurt, IO January 20I4).
} 
activities without authorisation in 2013 and ESMA was duly informed. ESMA then wrote to GPRC to require registration or cessation of activities. GPRC submitted an application to ESMA after a few correspondences and provided an application that was notified as 'complete' by ESMA. However, GPRC was denied registration after ESMA's compliance team took the view that GPRC was not in compliance with the substantive requirements of the Annex to the Credit Rating Agencies Regulation. GPRC contested I2 grounds of ESMA's decision. The Board of Appeal held that only one ground of ESMA's decision was not well-founded. Based on the appellant's failure to convince the Board that much of ESMA's grounds of decision were not well-founded, the Board dismissed GPRC's appeal.

Although the Board of Appeal upheld ESMA's decision not to register GPRC, the criticism made by GPRC against ESMA's grounds of decision highlighted the challenges for ESMA as a new regulatory body and the lessons that ESMA needed to learn. A number of ESMA's requirements for registration were in a qualitative manner that allowed ESMA to decide in its discretion whether an applicant satisfied the substantive requirements in question. Hence, the GPRC alleged that such requirements were unclear or opaque and did not provide adequate guidance on what was expected. For example, the applicant had to demonstrate that the applicant had adequate systems, resources and confidentiality safeguards. GPRC did not in ESMA's view demonstrate that it had adequate IT systems. GPRC contended that IT systems were being finalised and were constantly evolving anyway and that ESMA did not engage in adequate dialogue with GPRC to make an informed determination. The Board held that GPRC had the onus to satisfy ESMA of such adequacy and this was not done. The author of this article is of the view that the Board's conclusion is sound, but this example highlights the need for ESMA to learn from its experience of being scrutinised as it steps into the role of directly regulating credit rating agencies, and there is perhaps need to develop more precise guidelines and criteria to bridge the expectations between the regulator and the regulated, even if the empowering legislation is in favour of the regulator exercising a widely worded form of discretion. Overall, the author is of the view that ESMA rightly exercised the discretion not to register GPRC as its objective to safeguard the credibility of ratings issued in the EU would likely be compromised if it approved of an applicant while not being sufficiently satisfied that the latter was demonstrating a robust set-up, governance and work procedures. The author agrees that the onus lies on the applicant to satisfy ESMA of its eligibility under the published legislative standards, albeit widely worded, although this is no excuse for ESMA not to develop clarity in its criteria and to make transparent its decision-making processes.

The Board also stated that 'the registration of a credit rating agency is a new process, and recognises that the procedures will to an extent take time 
fully to work out. ${ }^{\mathrm{II} 8}$ The decision of the Board is measured and provides a constructive learning opportunity for ESMA to consider whether it can do more to provide guidance in terms of how its discretion may be exercised, so that any perceived opacity in terms of ESMA's expectations in the eyes of the regulated community may be addressed.

The two decisions have provided a good measure of insight into the interagency scrutiny, learning and feedback that could be carried out at the level of the Board of Appeal. Such decisions also go some way towards supporting the consolidation of agency identity, understanding of scope of responsibilities and powers, development of robust and credible practices and reinforcing agency autonomy and effectiveness generally. This Part has so far argued that the Joint Committee and Board of Appeal have provided the platforms for inter-agency learning and accountability to become an avenue for the consolidation of autonomy and effectiveness on the part of the three agencies. The next section reviews the literature and general arguments for inter-agency learning and accountability.

\section{Inter-agency Coordination and Accountability Generally}

Seidman and Gilmour, scholars of public administration, have likened inter-agency coordination to 'the twentieth-century equivalent of the medieval search for the philosopher's stone' that would answer all the problems of public administration'. ${ }^{119}$ Inter-agency coordination is necessary for government and the administrative state, but is fraught with challenges from the political, organisational and behavioural points of view.

The rise of the administrative state is often viewed as a necessary form of 'regulatory capitalism', ${ }^{\mathrm{I} 2}$ but the institution of agencies with specific remits may create a cluster of over-specialised administrative bodies with myopic visions and insular cultures, lacking in joined-up thinking. $\mathrm{Li}$ and Chan ${ }^{\text {I2I }}$ suggest that inter-agency coordination could promote information sharing, increased capacity and joined-up thinking to deal with unexpected contingencies and large-scale problems, as well as mutual reinforcement of each agency's responsibilities. They advocate this form of public administration in solving China's vast problem of urban pollution. Freeman

\footnotetext{
${ }^{118}$ ibid, para I88.

${ }^{119}$ Harold Siedman and R Gilmour, Politics, Position, and Power: From the Positive to the Regulatory State (OUP I986), $219 \mathrm{ff}$.

${ }^{120}$ David Levi-Faur, 'The Global Diffusion of Regulatory Capitalism' (2005) 598 The ANNALS of the American Academy of Political and Social Science I2, Giandomenico Majone, 'The Rise of the Regulatory State' (2007) I7 Western European Politics 77; Damien Geradin, 'The Development of European Regulatory Agencies: What the EU Should Learn from American Experience' (2004) II Columbia Journal of European Law I.

${ }^{\mathrm{I} 2 \mathrm{I}} \mathrm{W} \mathrm{Li}$ and Hon S Chan, 'Clean Air in Urban China: The Case of Inter-Agency Coordination in Chongqing's Blue Sky Program' (2009) 29 Public Administration and Development 55 .
} 
and Rossi ${ }^{122}$ also argue that inter-agency coordination holds much promise for pooling of resources and overall better and more transaction-cost efficient decision-making. Ongoing inter-agency coordination may promote the construction of a better information matrix, mutual trust between agencies and greater willingness to cooperate. Each agency can then pull its weight and develop more effective solutions especially in unexpected emergency situations. ${ }^{123}$ This could be especially relevant for the ESFS entities in their roles to safeguard financial stability in the EU.

Although fears and suspicions could be directed at inter-agency coordination as being potentially a form of agency collusion and consolidation of administrative power over regulated entities, the individual identities and purposes of agencies may counteract those tendencies, and instead produce an effect of inter-agency accountability. Freeman and Rossi, ${ }^{124}$ as well as Di Noia and Gargantini ${ }^{125}$ suggest that inter-agency accountability, a form of horizontal accountability, is useful for promoting better technocratic solutions as agencies may be less likely to succumb to regulatory capture, insular culture or regulatory arbitrage by the regulated entities.

Erkkilä $^{126}$ also argues that networked entities are in relationships of mutual accountability vis-a-vis each other as their technocratic nature allows them to act as peers in monitoring each other's discharge of responsibilities. Due to the technocratic nature of agencies, ${ }^{127}$ inter-agency accountability may also be more effective in scrutinising the quality of professional performance of the agency than popular channels of accountability.

Although inter-agency accountability is not as well-studied as popular channels of accountability such as political, judicial and stakeholder accountability, it is important to explore this channel of accountability as it serves a complementary and important purpose to popular channels of

\footnotetext{
${ }^{122}$ Jody Freeman and Jim Rossi, 'Agency Coordination in Shared Regulatory Space' (2012) I25 Harvard Law Review II34.

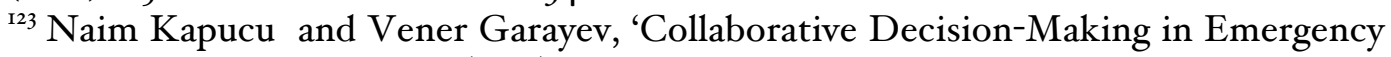
and Disaster Management' (20II) 34 International Journal of Public Administration 366.

${ }^{124}$ Jody Freeman and Jim Rossi, 'Agency Coordination in Shared Regulatory Space' (20I2) I25 Harvard Law Review II34.

${ }^{125}$ Carmine Di Noia and Matteo Gargantini, 'The European Securities and Markets Authority: Accountability towards EU Institutions and Stakeholders' (2013) at http://ssrn.com/abstract=2350I94 and in Pablo Iglesias Rodriguez (ed), Building Responsive and Responsible Financial Regulators in the Aftermath of the Financial Crisis (Intersentia 2013).

${ }^{126}$ Tero Erkkilä, 'Governance and Accountability - A Shift in Conceptualisation' (2007) Public Administration Quarterly I.

${ }^{127}$ Arndt Wonka and Berthold Rittberger, 'Perspectives on EU Governance: An Empirical Assessment of the Political Attitudes of EU Agency Professionals' (2OII) I8 Journal of European Public Policy 888.
} 
accountability. Dubnick et al ${ }^{\text {I28 }}$ argue that multiple channels of accountability for agencies are important as they are located in networks, and function like organic systems that seek to respond to the needs in the regulatory space.

In the EU context, particularly in new institutional architecture such as the ESFS, the SSM and SRM, it is important to explore how the design of such architecture meets the needs of credibility, effectiveness and legitimacy. This article has observed that due to concerns for appropriate restraint of power and popular accountability, the ESFS has been subject to complex design. However, such complex design poses potential handicaps to the technocratic development of the ESFS. The author acknowledges the necessity of those constraints such as in line with Treaty parameters and the Meroni doctrine, but suggests that the inter-agency nature of the institutional architecture can be exploited to enhance the technocratic leadership and effectiveness, as well as the accountability of the ESFS entities. It is submitted that further empirical research should be carried out on the nature of inter-agency accountability so that indicators can be developed for the maturation of this area of study. Such indicators can provide a roadmap for the development of more formal mechanisms in inter-agency accountability in order to enhance the purposes served by this form of accountability in ensuring agency effectiveness and output legitimacy.

The article now turns to the second stage of institutional development in the EU's financial regulation framework, the SSM and SRM. The SSM and SRM are also complex designs that reflect the compromises made allocating the power in micro-prudential supervision and the crisis resolution of key banks in the euro-area. These complex designs raise issues regarding how the balance of technocratic effectiveness and power structures can be achieved. Section 3 will argue that the inter-agency model in the ESFS provides useful insights for the SSM and SRM. These perspectives may be a starting point but can be used to develop future institutional design changes to secure an optimal balance in technocratic effectiveness and power structures.

\section{THE SSM, SRM AND LESSONS THAT CAN BE LEARNT WITH RESPECT TO INTER-AGENCY COORDINATION}

The SSM and SRM may be regarded as the second stage in reforming financial regulatory architecture in the EU. The continued weakness of many European banks post the global financial crisis affected market confidence and economic recovery in the EU, and the SSM was introduced

${ }^{\mathrm{I} 28}$ Melvin J Dubnick and H George Frederickson (eds), Accountable Governance: Problems and Promises (2010) Schillemann and Boven, reviewed by Thomas J Grietens, 'Moving the Study of Accountability Forward' (2012) 44 State and Local Government Review 76. 
to sever the links between weak sovereigns and national banks with poor balance sheets, in order to provide a more credible system of supervision and backstop for those banks. ${ }^{129}$ Troeger, ${ }^{130}$ however, argues that this is a poor reason for the SSM as it would only focus the SSM's attention on the most weakly disciplined banks to rectify their problems. In other words, he views the institution of the SSM as created not for reasons of coherence in regulatory ideology or architecture, but for fire-fighting the excesses due to poor national oversight. It remains to be seen if the priorities of the SSM may affect the inter-relationships between the SSM and the ESFS.

The SSM is a network comprising the ECB and national regulators. Certain responsibilities and tasks are conferred on the ECB, and national regulators are to act as the ECB's assistants and delegates. The ECB is empowered in the SSM to undertake microprudential supervision of banks that are not 'less significant ${ }^{\text {'13 }}$ in the euro area and banks of countries that have entered into close cooperation with the SSM. ${ }^{132}$ Such supervisory tasks include authorisation of credit institutions, ensuring compliance with micro-prudential legislation, stress testing and supervisory review, overseeing recovery plans and carrying out early intervention. To this end, the ECB may adopt guidelines and recommendations issued by the EBA or may issue its own to the end that is necessary for its responsibilities, subject to public consultation before the adoption of any such guidelines or recommendations. ${ }^{133}$ However, as the ECB will not have responsibility over all banks in the euro area, national regulators remain responsible for those banks, subject to a reporting duty to the ECB. ${ }^{\mathrm{I} 4}$

The SSM is to be independent of the ECB's monetary function. ${ }^{\mathrm{I} 5}$ It is to be governed by a Board of Supervisors ${ }^{136}$ comprising a Chair and ViceChair, four ECB representatives and a representative of each national regulator in the Member States subject to the SSM. The Chairperson is to

\footnotetext{
${ }^{129}$ Guido Ferranini and Luigi Chiarella, 'Common Banking Supervision in the Eurozone: Strengths and Weaknesses' (2013) at http://ssrn.com/abstract_id=2309897. ${ }^{130}$ Tobias H Troeger, 'The Single Supervisory Mechanism -Panacea or Quack Banking Regulation?' (2013) at http://ssrn.com/abstract=2311353.

${ }^{131}$ ie banks with assets totalling 30 billion euros or more, or ratio of total assets over the GDP of the relevant Member State exceeds $20 \%$, unless the total value of its assets is below 5 billion euros, an institution regarded by the national regulator as significant, an institution regarded by the ECB on its own initiative as significant, any institution receiving public financial assistance, and at least the three key banks in every euro area jurisdiction or member state in close cooperation. SSM Regulation, art 6.

${ }^{132}$ SSM Regulation, art 7.

${ }^{133}$ ibid, art 4.

${ }^{134}$ This seems to be a balanced form of necessary centralisation according to what may be most efficient and proportionate, see Jean-Edouard Colliard, 'Monitoring the Supervisors: Optimal Regulatory Architecture in a Banking Union' (2014) at http://ssrn.com/abstract=2274I64; SSM Regulation, art 6.

${ }^{135}$ SSM Regulation, arts 19 and 25.

${ }^{136}$ ibid, art 26.
} 
be appointed by open selection with Parliament and Council duly informed, while the Vice-Chair is to be appointed from the Board. The appointments are not particularly subject to political control, in line with the fierce boundaries of independence hitherto maintained by the ECB. Due to Treaty constraints, however, the Board of Supervisors is not able to adopt decisions for the SSM as such or the institution of the SSM may require Treaty change. Hence, the Board will send draft decisions to be adopted by the Governing Council of the ECB, which would be deemed to have accepted if no objection is raised in a maximum of $\mathrm{IO}$ days. ${ }^{137}$

The introduction of the ECB's leadership in the SSM as part of the financial regulation fabric at the $\mathrm{EU}$ may result in a marked power imbalance between the ESFS institutions and the ECB. Such institutional 'imbalance' has been observed and raised by a number of commentators. ${ }^{138}$ In contrast to the three agencies in the ESFS, the ECB has been an established and independent institution in the EU and the fear is that the maturing ESFS institutions may be adversely affected, especially the EBA. A number of commentators are concerned that the SSM will introduce a form of differentiated integration ${ }^{139}$ in euro area banking regulation and undermine the EBA's work in this area. ${ }^{\mathrm{I}}{ }^{\circ}$ Although the SSM is a member of and subject to the EBA, the ECB has the power to adopt its own supervisory guidelines and recommendations, and in carrying out national supervision, it would be applying nationally transposed versions of the Capital Requirements Directive IV which could reinforce certain national peculiarities. The leadership of the ECB in the SSM may result in the bifurcation of regulatory approaches for the euro area and the non-euro area. Such bifurcation or differentiation is not exactly ideal as cross-border banking in the EU is not so starkly divided along those lines, and the regulation of banks with pan-European footprint would benefit from joined-up thinking, the need for which formed the basis for the de Larosière recommendations for instituting the ESFS in the first place. The

${ }^{137} \mathrm{ibid}$, art 26. Ferran and Babis argue that this is adverse to non-euro area Member States in close cooperation as those Member States would not have a representative in the Governing Council, see Eilis Ferran and Valia SG Babis, 'The European Single Supervisory Mechanism' (2013) JCLS 255.

${ }^{138}$ Some queries have been raised in Benedikt Wolfers and Thomas Voland, 'Level the Playing Field: The New Supervision of Credit Institutions by the European Central Bank' (2014) 5I Common Market Law Review I463.

${ }^{139}$ Donato Masciandaro, Maria J Nieto and Marc Quintyn, 'Will They Sing the Same Tune? Measuring Convergence in the new European System of Financial Supervisors' (IMF Working Paper 2009) at http://ssrn.com/abstract=442244 suggests that central bank leadership in microprudential supervision generally fragments regulatory architecture in financial regulation.

${ }^{140}$ Eilis Ferran and Valia SG Babis, 'The European Single Supervisory Mechanism' (2013) JCLS 255; Klaus Lackoff, 'The Framework Regulation (FR) for the Single Supervisory Mechanism (SSM) - An Overview' (2014) 29 JIBLR 498, 'How will the Single Supervisory Mechanism (SSM) Function? A Brief Overview' (2014) 29 JIBLR I3; Concetta Brescia Morra, 'From the Single Supervisory Mechanism to the Banking Union: The Role of the ECB and the EBA' (2013) at http://ssrn.com/abstract=2448913. 
potential of the ECB to undermine the regulatory convergence role of the EBA would arguably be due to its relatively more established and powerful profile, the internalisation of an array of supervisory arrangements that could become insular vis a vis the ESFS, and the relatively lesser demands in accountability that reinforce its power.

The SSM is subject to no discernible ex ante political controls as even the appointment of the Chairperson of the Board of Supervisors is not subject to political control. The SSM is accountable to the Council and Parliament ${ }^{\mathrm{I} 4 \mathrm{I}}$ via annual reporting and the Chairperson may be asked to appear before the euro group in the Council or committees of the Parliament. The annual reports are also to be laid before national parliaments ${ }^{\mathrm{I} 42}$ of the Member States subject to the SSM, and national parliaments may request for the ECB's written explanations on matters raised by them. The ECB is also subject to accountability to regulated entities to whom it addresses its decisions. It has established an Administrative Board of Review ${ }^{\mathrm{I} 43}$ to deal with requests to review its decisions, to comprise of five independent banking and finance experts appointed by the ECB. The Board's decisions also need to be adopted by the Governing Council in the same way mentioned above. The largely $e x$ post reporting accountability for the SSM highlights the extent of ECB independence and discretion in the discharge of its tasks, very distinct from the institutions in the ESFS. The incentives for the ECB to engage in inter-agency accountability are arguably low as inter-agency accountability may be seen as an impediment to the wide berth of discretion enjoyed in its power and accountability structures.

There are certain junctures of inter-relationships between the SSM and ESFS. In the discharge of its responsibilities, the SSM is required under its instituting legislation to work with the institutions in the ESFS ${ }^{144}$ to consider how financial regulation may be effectively administered in the $\mathrm{EU}$ as a whole, put in place a system of coordination and delegation with participating Member State regulators ${ }^{145}$ and conclude memoranda of understanding with non-participating Member State regulators and with all Member States' securities regulators. ${ }^{146}$ The ECB would also be a

\footnotetext{
${ }^{\mathrm{I} 4 \mathrm{I}}$ SSM Regulation, art $2 \mathrm{O}$.

${ }^{142}$ ibid, art 2I.

${ }^{143}$ ibid, art 24.

${ }^{144}$ ibid, art 3 .

${ }^{145}$ ibid, art 6.

${ }^{\mathrm{I} 46} \mathrm{ibid}$, art 3 . It is uncertain yet how such coordination would work out but the European Commission is decisively of the view that 'The establishment of a Banking Union, and notably of the Single Supervisory Mechanism (SSM) and the Single Resolution Mechanism (SRM) as its key components, will impact the functioning of the ESFS, but does not call into question its existence and necessity.' See European Commission, Report from the Commission to the European Parliament and the Council on the operation of the European Supervisory Authorities (ESAs) and the European System of Financial Supervision (ESFS) (7 August 2014), 4.
} 
participating member of the EBA. ${ }^{\mathrm{I} 7}$ In order to address the concerns of Member States that are not subject to the SSM, readjusted voting rights for these Member States ${ }^{\mathrm{I}{ }^{8}}$ (i.e. to have these Member States' votes count in a separate class) have been introduced in the structure of decisionmaking in the EBA. However, this article predicts that institutional imbalance between the SSM and the ESFS could entail the following consequences: (a) the lack of synergies in micro-prudential regulation may ensue if the coordination between the ECB and the EBA does not take off, and the EBA could reassert its identity and authority by focusing more on areas that do not overlap with micro-prudential regulation, such as conduct regulation and the areas of inter-agency coordination in the Joint Committee; or (b) the EBA could compel the ECB to fall in line with its standards for convergence where it has the mandate to ensure such convergence, e.g. supervisory convergence, stress-testing and recovery and resolution plans, ${ }^{149}$ but it remains to be seen if boundary issues between the ECB and EBA may impede the effectiveness of either agency's discharge of responsibilities. Furthermore, it is questioned if the ESRB may be relegated in view of the $\mathrm{SSM},{ }^{150}$ as the ECB has certain specific macro-prudential powers ${ }^{15 \mathrm{I}}$ in respect of requiring extra capital buffers to be put in place, although the CRD IV ${ }^{152}$ designates the ESRB as the body that recommends whether any counter-cyclical buffer for any Member State should be introduced.

In sum, the imbalance between power and accountability structures of the SSM and the ESFS institutions may result in uncertain prospects for the achievement of technocratic effectiveness by all institutions concerned. Commentators do question the necessary superiority of central banks in micro-prudential supervision, ${ }^{153}$ and the ECB's role in the episode regarding the rescue of Cyprus' banks in 2013 was not a particularly applauded one. ${ }^{154}$ This article suggests that some lessons can be learnt from the ESFS in order to secure some of the advantages in relation to enhancement to technocratic effectiveness, accountability and legitimacy

\footnotetext{
${ }^{147}$ ibid.

${ }^{148}$ Regulation (EU) No I022/2OI3 of the European Parliament and of the Council of 22 October 2013 amending Regulation (EU) No I093/2010 establishing a European Supervisory Authority (European Banking Authority) as regards the conferral of specific tasks on the European Central Bank pursuant to Council Regulation (EU) No $1024 / 2 \mathrm{OI}_{3}$ [2013] OJ L 287/5, amendment to art 44 of the EBA Regulation.

${ }^{149}$ Francesco Guarracino, 'Role and Powers of the ECB and of the EBA: In the Perspective of the Forthcoming Single Supervisory Mechanism' (2014) at http://ssrn.com/abstract=2319136.

${ }^{150}$ Eddy Wymeersch, 'The Single Supervisory Mechanism or "SSM", Part One of the Banking Union' (2014) NBB Working Paper.

${ }^{15 \mathrm{I}}$ SSM Regulation, art 5.

${ }^{152}$ CRD IV Directive, arts I25-I26.

${ }^{153}$ Donato Masciandaro and Maria J Nieto, 'Governance of the Single Supervisory Mechanism: Some Reflections' (2013) at http://ssrn.com/abstract $=2384594$.

${ }^{154}$ 'Cyprus plans capital controls and bank restructuring as ECB sets ultimatum - as it happened', The Guardian (21 March 2013).
} 
as discussed earlier. In particular, the SSM could be subject to more overt inter-agency learning and coordination with the ESFS. For example, where there may be boundary contests between the SSM and EBA such as in micro-prudential standard setting, the express institution of inter-agency coordination and learning in those respects may provide opportunities for joined-up thinking in both the setting of micro-prudential regulatory and supervisory standards. This article is not advocating that joined-up thinking necessarily means uniform thinking or one-size-fits-all standards across the EU. Such joined-up thinking is necessary so that issues of convergence or uniformity, or differentiation, where it is warranted, are considered holistically and coherently. Such formal inter-agency coordination could mitigate the risk of inefficient bifurcation in the regulatory regimes for euro-area and non euro-area banks.

It may, however, be argued that a new form of inter-agency coordination and accountability that checks on the ECB's powers in the SSM is instituted in the form of the Single Resolution Mechanism (SRM). A number of commentators have at the early discussions regarding the institution of the SSM voiced concerns regarding the lack of a supporting single resolution mechanism which is necessary to complete the picture for effective centralised micro-prudential supervision. ${ }^{155}$ Ferran argues that the SRM together with the SSM is necessary to make the integrated market in banks work and to prevent re-nationisation of banks in the EU. ${ }^{156}$ The SRM has been finalised in July $2014 \cdot{ }^{157}$

The SRM establishes a single resolution mechanism for banks subject to the SSM. The SRM is to be directed by a Board (SRB), which is an independent agency with separate legal personality independent of the $\mathrm{ECB},{ }^{158}$ and will be responsible for drafting resolution plans, adopting early intervention measures imposed under the SSM, adopting resolution decisions and carrying out the administration of resolution. ${ }^{59}$ The Board will comprise a Chair, Vice-Chair, and four other full-time members to be appointed by the Parliament based on a shortlist recommended by the Commission, and the representatives of the national resolution authorities of participating Member States. ${ }^{160} \mathrm{~A}$ representative of each of the ECB and the Commission may attend at the plenary ${ }^{16 \mathrm{I}}$ and executive sessions of

\footnotetext{
${ }^{155}$ Kern Alexander, 'Bank Resolution and Recovery in the EU: Enhancing Banking Union?' (2013) I4 ERA Forum 8r; Daniel Gros and Dirk Schoenmaker, 'European Deposit Insurance and Resolution in Banking Union' (2014) 52 JCMS.

${ }^{156}$ Eilis Ferran, 'European Banking Union: Imperfect but it can Work' (2014) at http://ssrn.com/abstract $=2426247$.

${ }^{157}$ SRM Regulation.

${ }^{158}$ SRM Regulation, art 42.

${ }^{159}$ ibid, art 7 .

I60 ibid, arts 43, 53 .

${ }^{161}$ The plenary sessions are annual in nature and deal with important issues such as adoption of work programme and budget, SRM Regulation, arts 46-48. The executive sessions are relevant to the Chair, Vice-Chair and four full-time members
} 
the Board as permanent observers. ${ }^{162}$ The Parliament's role in appointment may constitute a form of input control of the constitution of the Board that countervails the relatively autonomous ECB in its SSM leadership.

The SRM is structured in such a way as to offer opportunities for interagency coordination and accountability with the SSM. The discussion below explores the junctures of possible inter-agency coordination and learning. However, at the moment, these are framed as divisions of responsibilities and it is unclear how inter-agency coordination may take place. This article suggests that the overt framing of inter-agency coordination can mitigate boundary issues and promote more technocratic effectiveness through inter-agency learning and coordination. More informal guidelines can be agreed upon between the SSM and SRM in due course to foster inter-agency coordination and the ESFS should be also more overtly drawn into the inter-agency coordination and learning relationships.

The interface between the SSM and SRM is as follows. The SRM is responsible for drawing up resolution plans in dialogue with the ECB and national regulators, ${ }^{163}$ and determining whether a bank faces impediments to its resolvability. ${ }^{164}$ The SSM is responsible for implementing the resolution plans adopted by the SRB or removing impediments to resolvability according to the SRB's instructions. As the SSM becomes an implementer of the SRM's decisions on resolution plans, this provides a check on the SSM's micro-prudential supervisory role and feedback from the SRM could provide learning opportunities for the SSM. However, depending on the power dynamics between the SSM and the SRM, it remains to be seen if the SRM is able to take technocratic leadership on its tasks and not be overwhelmed by ECB expertise, and whether the SSM and SRM would engage in such feedback and dialogue. Furthermore, the SRM is tasked to monitor early intervention measures taken by the SSM, which need to be informed to the SRM. The SSM has leadership in managing the run-up to any bank crisis in the form of early intervention, but the SRM and Commission would monitor the early intervention measures to ensure that there would be a seamless transition to resolution if that becomes necessary. ${ }^{165}$ It remains open to observation how such coordination would work out. ${ }^{166}$ The dividing line between early intervention and crisis resolution is a shifting one and there is ample opportunity for the SSM and SRM to coordinate on this and share

only and deal with the executive management of the Board's tasks including preparatory work for the plenary sessions, SRM Regulation, arts $5 \mathrm{I}^{-} 52$.

${ }^{162}$ ibid, art 43.

${ }^{163}$ ibid, art 8.

${ }^{164}$ ibid, art Io.

${ }^{165}$ ibid, art 13 .

${ }^{166}$ Remarks by Rosa Lastra on Charles Goodhart and M Sevagiano, 'The Determination of Bank Recovery' at the 'Law and Monetary Policy' Conference, University of Sheffield, io September 2014. 
information. These interfaces provide opportunities for inter-agency coordination and learning and this article suggests that such opportunities can be framed into more overt inter-agency frameworks instead of being regarded as boundaries of responsibility division. Such overt frameworks may go some way towards mitigating institutional imbalance between the ECB in the SSM and the SRM, and could allow inter-agency learning and coordination to strengthen each agency's technocratic expertise and effectiveness.

However, could it be argued that the SRM is nevertheless weak as an institution as it is tightly subject to political control and accountability, and so does not provide institutional balance to the powerful ECB in the SSM? There is a danger that the ECB could still dominate the SRM's role as the ECB plays the part of determining (upon consultation with the Board) if an entity is failing or likely to fail and in need of resolution. ${ }^{167}$ However, the SRM still determines if a resolution decision should be proposed according to the objectives and principles governing resolution. ${ }^{168}$ Furthermore, the SRM needs to submit a resolution decision to be adopted jointly by the Commission ${ }^{169}$ within 24 hours of notification by the SRM, and by the Council ${ }^{170}$ within 12 hours of notification by the Commission. The decision-making mechanism for the crucial resolution decision involves extensive political control. This is possibly warranted as resolutions of national banks are matters of key national interest in many bank-based economies in the EU. The political control over the SRM could provide an indirect political check on the ECB's dominance in financial stability oversight in general. In that vein, the SRB's power to determine that the Single Resolution Fund needs to be called upon to financially assist any ailing bank is checked by the Commission which has powers to assess the appropriateness of State aid. ${ }^{171}$ The political control and accountability structures for the SRM could even act as countervailing forces against ECB dominance at the juncture of the inter-relationships between the SSM and SRM. Hence, the author supports more overt framing of the SRM-SSM inter-agency coordination to mitigate institutional imbalance introduced by the SSM.

The SRM also interacts with the ESFS in terms of its coordination with the EBA. The SRM has the power to notify the EBA of any institutions it views as unresolvable, ${ }^{172}$ and so the $\mathrm{EBA}$ is brought into the dialogue. Furthermore, the EBA remains responsible for drafting the technical standards, implementing technical standards and guidelines for the Recovery and Resolution Directive that applies to all SSM and non-SSM

\footnotetext{
${ }^{167}$ SRM Regulation, art I8(I)(a).

${ }^{168}$ ibid, arts I4, I5.

169 ibid, art I8.

${ }^{170}$ ibid.

${ }^{171}$ ibid, art I9.

${ }^{172}$ ibid, art IO.
} 
Member States. Thus, there is potential for inter-agency coordination and accountability between the SRM and the EBA. This article suggests more overt framing of inter-agency coordination between the SRM, SSM and the EBA so that a multiple-agency architecture can arise for specific areas of coordination. This not only helps to check ECB dominance in the SSM, but would also help consolidate the SRM's and EBA's burgeoning identities and technocratic leadership.

That said, the author is mindful that the dynamics of the new interrelationships remain uncertain. A differentiation may occur between the SRM-SSM which are responsible for the euro-area financial institutions and the ESFS which may focus on the non-euro area if marginalised by the SSM-SRM domination in the case of euro-area financial institutions. Such differentiation would arguably be lamentable as certain advantages may be foregone - the benefits of joined-up thinking in EU financial regulation and the mutual strengthening of the relatively new institutions in the financial regulation architecture. The author is concerned about the prospect of agency-led differentiation in EU financial regulation for the euro area and non-euro area, and argues that the suggestions made above regarding how inter-agency coordination may work between the ESFS, SSM and SRM could go some way towards mitigating the prospect of such differentiation.

In sum, the second stage of institutional reform in the financial regulatory architecture in the EU has brought about more complexity in the multipleagency structure. Such complexity, as discussed in the context of the ESFS, could work towards boosting agency independence, effectiveness and inter-agency accountability. However, the ESFS has an overall coherent structure, identical mandates and comprises of entities at similar stages of development and maturity. The new complexity brought about by the SSM and SRM may introduce confusion in power dynamics in terms of institutional imbalance and lack of clarity in the boundaries of responsibilities. Furthermore, synergies in joined-up thinking in EU financial regulation may be lost if institutional dynamics veer towards a differentiation between SSM-SRM led oversight for euro-area financial institutions and the ESFS for the rest. This article suggests that insights from inter-agency coordination may provide a roadmap towards promoting better institutional balance, inter-agency learning and the consolidation of burgeoning agencies' responsibilities, identities and competence. Such roadmap would also mitigate against the trajectory towards differentiated integration between financial regulation in the euro and non-euro areas. Inter-agency learning and coordination could also in due course enhance inter-agency accountability and the overall accountability and legitimacy of the EU financial regulatory architecture.

\section{Final Observations ANd Conclusions}


This article first addresses the multiple-agency regulatory architecture in the ESFS which comprises of an oft-criticised sectoral approach. It argues that in the context of the EU, the three agencies and the Joint Committee and ESRB could provide a viable and sound approach to EU financial regulation as inter-agency learning and coordination, as well as accountability could help enhance each of the ESFS institutions' growth, maturity and development in technocratic leadership, and could be perceived to be more legitimate and effective than a centralised and monolithic entity. The concepts of inter-agency coordination and accountability are explored and observations are provided on how they work in the Joint Committee and Board of Appeal. The experiences of the Joint Committee and Board of Appeal provide useful lessons for interagency learning and accountability and further empirical research on these concepts could be useful for developing a concept of legitimacy for EU agencies.

The article then examines potential ramifications for the inter-agency architecture in EU financial regulation with the introduction of the SSM and SRM. The inter-agency framework has become more complex and there are concerns regarding the SSM becoming differentiated and monolithic, undermining the rest of the ESFS especially the EBA and ESRB. This is largely due to the dominance of an already powerful and autonomous ECB in the SSM, and the ECB would hardly need to consolidate its identity and leadership through greater inter-agency coordination and accountability with the rest of the ESFS. Would the SSM and EBA be able to coordinate in terms of supervisory convergence in micro-prudential supervision? Would the SRM and SSM be able to work with each other in the shift from early intervention to crisis resolution; and with the EBA in a single rulebook for recovery and resolution? The SSM is placed in a position where opportunities to coordinate with the SRM and EBA occur, but such interfaces are not framed as opportunities for interagency learning and coordination but as divisions of responsibility at present. This article advocates more overt framing of inter-agency coordination and learning between the SSM, SRM and EBA in order to achieve better institutional balance and secure greater consolidation of the burgeoning institutions' technocratic leadership and identities. The promotion of inter-agency accountability could greatly enhance the new and more complex financial regulatory architecture, and perhaps prevent inefficient forms of differentiated financial regulation from occurring between the euro area and non-euro area. Furthermore, in light of the comparatively more powerful ECB in the matrix, the Parliament review's call to boost the three agencies' Chairpersons' peer status vis-a-vis the Commission may be useful. ${ }^{173}$

${ }^{173}$ DG for Internal Policies, Parliament's Review of the ESFS (2013). 
A multiple-agency approach at the EU may seem complex and anachronistic, but this article has pointed out the potential for making inter-agency coordination and accountability work. These observations may help in the outworking of the SSM and SRM and in the wider context of EU agencies, their effectiveness and legitimacy. 